\title{
Boosting Selectivity and Sensitivity to Biomarkers of Quantum Resistive Vapour Sensors Used for Volatolomics with Nanoarchitectured Carbon Nanotubes or Graphene Platelets Connected by Fullerene Junctions
}

\author{
Sananda Nag ${ }^{1,2}$, Mickaël Castro ${ }^{1}\left(\mathbb{D}\right.$, Veena Choudhary ${ }^{2}$ and Jean-Francois Feller ${ }^{1, *(D)}$ \\ 1 Smart Plastics Group, University of South Brittany (UBS), IRDL CNRS 6027, 56321 Lorient, France; \\ sananda126@gmail.com (S.N.); mickael.castro@univ-ubs.fr (M.C.) \\ 2 Centre for Polymer Science and Engineering, Indian Institute of Technology, Delhi 110016, India; \\ veenac@polymers.iitd.ac.in \\ * Correspondence: jean-francois.feller@univ-ubs.fr
}

check for updates

Citation: Nag, S.; Castro, M.; Choudhary, V.; Feller, J.-F. Boosting Selectivity and Sensitivity to Biomarkers of Quantum Resistive Vapour Sensors Used for Volatolomics with Nanoarchitectured Carbon Nanotubes or Graphene Platelets Connected by Fullerene Junctions. Chemosensors 2021, 9, 66. https://doi.org/10.3390/ chemosensors 9040066

Academic Editor:

Nicole Jaffrezic-Renault

Received: 24 February 2021

Accepted: 24 March 2021

Published: 28 March 2021

Publisher's Note: MDPI stays neutral with regard to jurisdictional claims in published maps and institutional affiliations.

Copyright: (c) 2021 by the authors. Licensee MDPI, Basel, Switzerland. This article is an open access article distributed under the terms and conditions of the Creative Commons Attribution (CC BY) license (https:/ / creativecommons.org/licenses/by/ $4.0 /)$.

\begin{abstract}
Nanocarbon-based vapour sensors are increasingly used to make anticipated diagnosis of diseases by the analysis of volatile organic compound (VOC) biomarkers from the breath, i.e., volatolomics. However, given the tiny number of molecules to detect, usually only tens of parts per billion (ppb), increasing the sensitivity of polymer nanocomposite chemoresistive transducers is still a challenge. As the ability of these nanosensors to convert the interactions with chemical compounds into changes of resistance, depends on the variations of electronic transport through the percolated network of the conducting nanofillers, it is a key parameter to control. Actually, in this conducting architecture, the bottlenecks for electrons' circulation are the interparticular junctions giving either ohmic conduction in the case of close contacts or quantum tunnelling when jumps though gaps are necessary. This in turn depends on a number of nanometric parameters such as the size and geometry of the nanofillers (spherical, cylindrical, lamellar), the method of structuring of the conductive architecture in the sensory system, etc. The present study focuses on the control of the interparticular junctions in quantum-resistive vapour sensors (vQRS) by nanoassembling pristine CNT or graphene covalently or noncovalently functionalized with spherical Buckminster fullerene $\left(\mathrm{C}_{60}\right)$ into a percolated network with a hybrid structure. It is found that this strategy allows us to significantly boost, both selectivity and sensitivity of pristine CNT or graphene-based transducers exposed to a set of seven biomarkers, ethanol, methanol, acetone, chloroform, benzene, toluene, cyclohexane and water. This is assumed to result from the spherical fullerene acting on the electronic transport properties at the nanojunctions between the CNT or graphene nanofillers.
\end{abstract}

Keywords: vapour sensors; nanocomposites; graphene; CNT; hybrids; cancer biomarkers; conductive junctions; fullerene; e-nose; volatolomics

\section{Introduction}

The demand for the development of miniaturized sensors arrays for fast, low-cost, low-power detection and discrimination of volatile organic compounds (VOC) has increased dramatically over the years. In particular, the detection and identification of biomarkers in the volatolome (volatiles emitted by the human body) should lead to the development of novel, noninvasive anticipated diagnostic methods for a wide range of diseases. The promise of "volatolomics" [1,2] is to detect at their very early stages of development different types of cancer [3-9], tuberculosis [10,11] liver failure [12], kidney failure [13], Parkinson's disease [14], and many others [15-19]. The spheres of application of VOC sensing beyond medicine are food degradation monitoring [20-22], environment monitoring, i.e., the indication of hazardous chemical leakage, the monitoring of organic 
solvent vapour concentration in the air [23-26], space exploration, and homeland security [27-30], process control of chemical and food production [31], the monitoring of quality and alcohol content in automotive fuel [32,33] and others [34]. Nanomaterials belonging to fullerene family are already proved to act as a well-recognized component for elaboration of VOC sensors.

Fullerenes are fully carbonaceous molecules that can be planar, hollow, spherical or tubular in shape. Carbon nanotubes (CNT), graphene nanoplatelets (GNP), Buckminster fullerenes $\left(C_{60}\right)$, each of which are allotropes of carbon belonging to fullerene family, have attracted tremendous research interest since their discovery because of their unique physicochemical properties. $\mathrm{C}_{60}$ are zero dimensional with discrete molecular weight, while CNT and graphene are one and two dimensional, respectively, with anisotropic structure and broad molecular weight distribution. However, each of these carbon allotropes is composed of $\mathrm{sp}^{2}$ hybridized carbon atoms, making them electrically conductive [35]. However, the electrical conductivity of $\mathrm{C}_{60}\left(10^{-14}-10^{-8} \mathrm{~S} \cdot \mathrm{cm}^{-1}\right)$ is much lower than that of CNT or graphene $\left(\approx 10^{5} \mathrm{~S} \cdot \mathrm{cm}^{-1}\right)$.

Among the fullerene family, pristine $\mathrm{CNT}$ is considered as a suitable candidate for vapour sensing because of its quick change in conductivity, dielectric constant or capacitance with the adsorption of gas or vapour molecules [16,36]. Graphene is also expected to perform well as a chemical vapour sensor, since the absorption of individual gas molecules onto graphene-based sensor brings about significant changes in electrical resistance [37]. Moreover, because of the high carrier mobility of graphene [38,39], room temperature sensitivity and high signal-to-noise ratio $[40,41]$ are achievable with graphene based quantum resistive sensors. Unfortunately its poor dispersibility in organic solvents, its inability to control chemical selectivity (due to surface property), its low sensitivity to vapour molecules (due to small junction gap) and hence poor tunnelling effect, are the shortcomings that restrict the use of pristine CNT or graphene in vapour sensing [42,43].

Another carbon allotrope belonging to the fullerene family is Buckminster fullerene $\left(\mathrm{C}_{60}\right)$ discovered in 1985 by Kroto et al. [44]. However, the true research interest in this material has been minor until 1990 where Kratschmer et al. developed a method of synthesis in macroscopic quantities [45]. $\mathrm{C}_{60}$ consists of polyhedral pentagonal-hexagonal carbon rings with each carbon atom bonded to three other neighbours. $C_{60}$ has drawn appreciable research interest for several decades because of its exceptional physical, chemical and electronic properties, such as very high reactivity, excellent solubility in organic solvents, very high surface-to-volume ratio, high electron mobility $\left(\sim 0.1 \mathrm{~cm}^{-2} \cdot \mathrm{V}^{-1} \cdot \mathrm{S}^{-1}\right)[46]$ and free electron trapping ability [47,48]. It is considered as a novel electron pool $\Pi$ system [49]. In addition, $\mathrm{C}_{60}$ can be reduced readily because of the presence of low energy LUMO, which are triply degenerated t1u orbitals. Even they can be readily be polymerized into directly linked fullerene nanotubes by the application of pressure, temperature or light. One potential application of $\mathrm{C}_{60}$ is hydrogen storage since it can bind a number of hydrogen molecules without structure disruption [50]. In addition, the gas sensing characteristics of $\mathrm{C}_{60}$ were studied by Sakurai et al. [51] observing the change of electrical conductivity upon exposure to gases such as ammonia, acetaldehyde, etc.

The literature studies reveal that the hybridization of $\mathrm{C}_{60}$ with polymers, various organic molecules or different nanomaterials by covalent or noncovalent techniques may provide synergistic combination of the properties of both of the two components, hence making them attractive for a number of electronic and optical applications. Yu et al. developed covalently bonded $\mathrm{C}_{60}$-Graphene hybrids for bulk heterojunction polymer photovoltaic devices such as solar cells [52]. Immobilized $\mathrm{C}_{60}-\mathrm{SWCNT}$ complexes were synthesized by $\mathrm{Li}$ et al. via a microwave induced functionalization approach for same application in polymer photovoltaic cells. These devices could exploit the strong electron accepting feature of $\mathrm{C}_{60}$ and the high electron transport ability of CNT [53]. Liu et al. developed $\mathrm{C}_{60}$-graphene hybrids by covalent techniques for superior nonlinear optical properties [54]. $\mathrm{C}_{60}$-graphene hybrids were also prepared by Zhang et al. by chemical coupling between graphene oxide and pyrrolidine fullerene for potential application in solar cells or optical 
limiting devices [55]. Song et al. fabricated fullerene decorated CNT for application in flame-retardant polypropylene. Flame retardancy could be enhanced by utilizing the free electron accepting property of $\mathrm{C}_{60}$ with the barrier property of CNT [56]. However, without any covalent functionalization of their surface, the nanocarbons interact thanks to the van der Waals interactions, which are well described by a Lennard-Jones potential as modelled by Girifalco et al. [57]. Thus, they can naturally stack to create graphitic structures by self-assembly.

By the control of the geometry and the dispersion of the nanofillers, conductive architecture, organic functionality, etc., it is possible to achieve a concerted disconnection of the percolated network on chemical stress, leading to large change in electrical resistance. The sensitivity of the CNT or graphene-based chemo-resistive sensors can, however, be tuned by the control of the tunnel junctions in the percolated network. A first strategy consists in building a hierarchical structure of hard PMMA microbeads bridged by CNT to form a segregated network, in which the development of a high specific surface can enhance the sensitivity of CNT by $240 \%$ while keeping the original selectivity of CNT unaltered [58]. A second strategy to improve the sensitivity of the sensors consists in preventing the aggregation between nanocarbons in the conducting network by separating them with "spacers" in order to make the conductive architecture more easily disconnectable. The effectiveness of the different kinds of "spacers" to enhance conductive polymer nanocomposites' (CPC) sensitivity has been evidenced in different configurations: cyclodextrins [41] and POSS [59] with CNT, AgNP [60] and $\mathrm{Fe}_{3} \mathrm{O}_{4}$ [61] with graphene.

In this study, the idea was to graft Buckminster fullerenes $\left(\mathrm{C}_{60}\right)$ onto carbon nanotubes (MWNT) and reduced graphene oxide (rGO) to build a novel conductive architecture easily disconnectable by the presence of nanoscopic $\mathrm{C}_{60}$ at junctions. The robustness of the hybrid network should be ensured by a combination of two nanostructuring strategies, selfassembly and spray layer-by-layer (sLbL) deposition $[60,62,63]$ to control the 3D conductive architecture of chemo-resistive transducers. The approach of inserting spherical $\mathrm{C}_{60}$ at CNT or GNP junctions to enhance the sensitivity of single carbon nanofiller based chemoresistive vapour sensors has to be significant enough to justify an implementation into an electronic nose to improve its discrimination ability of a set of disease biomarkers. The final objective is to keep these sensing performances at the $\mathrm{ppb}$ level required to make a sharp diagnosis by volatolomics.

\section{Materials and Methods}

\subsection{Materials}

Multiwall carbon nanotubes (NC 7000) were kindly provided by Nanocyl S.A. (Sambreville, Belgium). This series of multiwall carbon nanotubes are produced via a catalytic carbon vapour deposition (CVD) process. Nanotubes which exit the reactor are then purified to greater than $90 \%$ carbon to produce the NC 7000 grade. These CNT have average mean diameter of $9.5 \mathrm{~nm}$, average length of $1.5 \mu \mathrm{m}$. CNT were used in the same manner as received from the production source without purification. Graphene oxide (GO) was synthesized from natural graphite powder by a modified Hummer's method [64] followed by reduction with hydrazine hydrate at $100{ }^{\circ} \mathrm{C}$ under reflux condition for $24 \mathrm{~h}$ to give reduced graphene oxide (rGO). Fullerene- $\mathrm{C}_{60}$ of $99.5 \%$ purity was purchased from Sigma Aldrich (Saint-Quentin Fallavier, France). All solvents, ethanol, methanol, acetone, chloroform, benzene, toluene, and cyclohexane, obtained from Acros Organics (Antwerp, Belgium) were used as received.

\subsection{Synthesis of Hybrid Nanomaterials}

In the first step of synthesis, lithiated CNT were produced by the dropwise addition of n-butyl lithium (in hexane) into a dispersion of CNT in toluene under the condition of continuous stirring and nitrogen protection. In the next step the lithiated CNT is reacted with a large excess of Buckminster fullerene by a nucleophilic addition reaction, resulting in $\mathrm{C}_{60^{-}} \mathrm{g}$-CNT as described in Figure 1. $\mathrm{C}_{60^{-}} \mathrm{g}-\mathrm{rGO}$ was then produced following a similar 
procedure as for $\mathrm{C}_{60}-\mathrm{g}-\mathrm{CNT}[52]$.
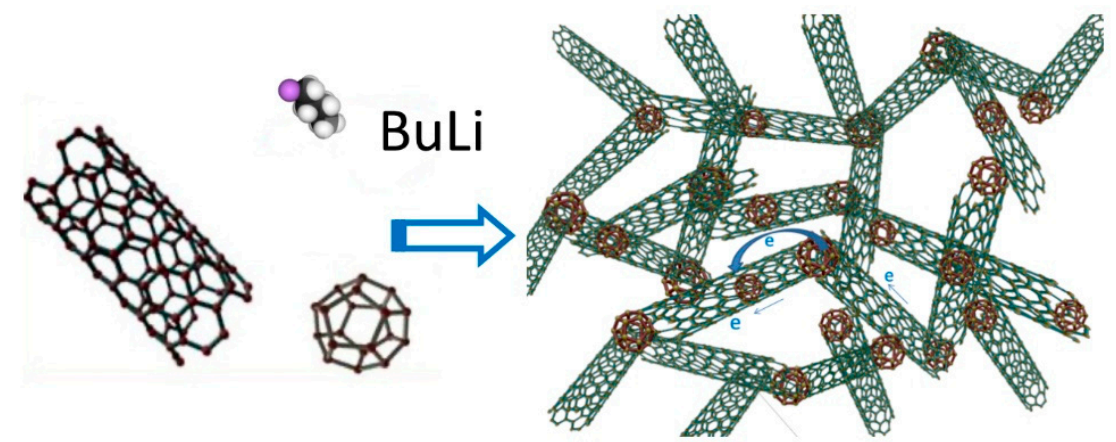

Figure 1. Schematics for synthesis of CNT-g-C60.

\subsection{Fabrication of Sensors}

For the fabrication of vapour sensors, first $\mathrm{C}_{60^{-}} \mathrm{g}-\mathrm{CNT}$ or $\mathrm{C}_{60^{-}} \mathrm{g}-\mathrm{rGO}$ hybrids were dispersed in chloroform under ultrasonication for $1 \mathrm{~h}$ at $50{ }^{\circ} \mathrm{C}$ with a Branson 3510 device $(100 \mathrm{~W}, 40 \mathrm{kHz})$. In the second step, vapour sensors were processed by the spray deposition layer-by-layer ( $\mathrm{LbL}$ ) technique $[43,65]$ onto homemade interdigitated electrodes. The sensors were dried in controlled atmosphere at $30^{\circ} \mathrm{C}$ for $8 \mathrm{~h}$. The initial resistance of all the sensors used in this study was adjusted within the $R_{0}=8 \pm 3 \mathrm{k} \Omega$ range, so that only the composition and not the variation of initial resistance may be considered to be responsible for any variation of molecular selectivity of the sensors when exposed to a set of VOC cancer biomarkers. The details of composition of the hybrid sensors are provided in Table 1.

Table 1. Characteristics of hybrid sensors.

\begin{tabular}{ccc}
\hline Nature & Process & $\mathbf{R}_{\mathbf{0}}(\mathbf{k} \boldsymbol{\Omega})$ \\
\hline CNT & 2 layers of CNT solution in chloroform sprayed & $5 \pm 2$ \\
CNT-g-C 60 & 2 layers of $\mathrm{C}_{60}$-g-CNT solution in chloroform sprayed & $8 \pm 3$ \\
CNT-1-C 60 & 1 layer of CNT solution in chloroform sprayed followed by spray of 1 & $4 \pm 2$ \\
rGO & layer of $\mathrm{C}_{60}$ solution in toluene & $10 \pm 4$ \\
rGO-g-C 60 & 5 layers of rGO solution in acetone sprayed & $10 \pm 5$ \\
\hline
\end{tabular}

\subsection{Characterization Techniques}

Thermo gravimetric analysis was carried out on the Pyris 6 TGA instrument of Perkin Elmer in a nitrogen atmosphere at a heating rate $20^{\circ} \mathrm{C} \cdot \mathrm{min}^{-1}$ in the temperature range $50{ }^{\circ} \mathrm{C}$ to $750{ }^{\circ} \mathrm{C}$ in order to calculate the amount of $\mathrm{C}_{60}$ grafted on to CNT or rGO. The architecture of as-synthesized nanohybrids was observed by morphological analysis such as atomic force microscopy (AFM) and scanning electronic microscopy (SEM). The nanoscale characterizations were done using AFM in ambient conditions using light tapping mode (TM-AFM) on a calibre multimode scanning probe microscope from Bruker-Veeco, Lille, France. For AFM observation, sample's preparation was done by spin coating onto freshly cleaved silicon substrate at $2500 \mathrm{rpm}$ for $30 \mathrm{~s}$ using SPIN150-NPP (SPS-Europe), followed by evaporation of the solvent. The morphology was also observed under the Zeiss Evo series scanning electron microscope model (Evo 50 SEM).

\subsection{Dynamic Vapour Sensing}

The chemo-resistive properties of the fabricated sensors were studied by measuring the electrical resistance when exposed alternatively to a 5 min cycles of dry nitrogen and saturated VOC while the sensors were placed in a $100 \mathrm{~mm} \times 10 \mathrm{~mm} \times 3 \mathrm{~mm}$ chamber with 10 slots. As one can see, the amplitudes are very similar and thus the error bar would not be clearly visible. 
The dynamic vapour sensing device is provided with a mass flow controller, solvent bubbler, electrical valves controlled by LabView software program and Keithley 6517 multimetre. The total flow rate is kept constant at $100 \mathrm{~cm}^{3} \cdot \mathrm{min}^{-1}$. The chemo-resistive response of nanocarbon based sensors can be expressed by calculating the relative amplitude of electrical signals $(A r)$ against solvent according to Equation (1).

$$
A_{r}=\frac{R-R_{0}}{R_{0}}
$$

where $R_{0}$ and $R$ are the initial resistance of the sensor in pure nitrogen and the resistance of the sensor in the presence of solvent vapour, respectively.

The vapour sensing performances of sensors under exposure of only ppm-ppb level concentration of VOC was carried out using a combination of LabView software and OVG-4 device, a versatile chemical vapour generator which consist of two main sections, the oven and the flow control system. The flow control system comprises of sample flow and split flow. The sample flow was kept fixed at $100 \mathrm{~cm}^{3} \cdot \mathrm{min}^{-1}$ and split flow was varied to alter the concentration of vapour at a fixed temperature. For each analyte, permeation tubes have been prepared following the providers' recommendations (https: / / www.owlstoneinc. com/products/build-your-own-permeation-tubes / accessed on march 2021). For instance, the permeation rate at a given temperature (that depends on the length of the tube and the nature of the solvent) was $1005 \mathrm{ng} \cdot \mathrm{min}^{-1}$ at $35^{\circ} \mathrm{C}, 796 \mathrm{ng} \cdot \mathrm{min}^{-1}$ at $40^{\circ} \mathrm{C}, 2335 \mathrm{ng} \cdot \mathrm{min}^{-1}$ at $40{ }^{\circ} \mathrm{C}$ and $2360 \mathrm{ng} \cdot \mathrm{min}^{-1}$ at $40^{\circ} \mathrm{C}$ for water, methanol, toluene and benzene, respectively. Thus, by acting on the sample flow $\left(100 \mathrm{~cm}^{3} \cdot \mathrm{min}^{-1}\right)$, the exhaust flow $\left(\mathrm{cm}^{3} \cdot \mathrm{min}^{-1}\right)$ for a fixed detector flow of $100 \mathrm{~cm}^{3} \cdot \mathrm{min}^{-1}$, the concentration of benzene was $410 \mathrm{ppb}$. The calibration of analytes' concentrations lasting one day per volatile organic compound, only eight biomarkers were tested at two concentrations at 1000 and $400 \mathrm{ppb}$. In this range the evolution of the amplitude of the chemo-resistive response Ar is assumed to be linear with the amount of analyte molecules when Langmuir adsorption is concerned, as already established in previous works $[26,66,67]$. Then, at higher contents, over several ppm, another linear range corresponding to Henry diffusion will be found and finally, over thousands of ppm, (more than $50 \%$ of saturation) clustering will take place. To describe this complete chemo-resistive behaviour on the whole range of concentrations, the LHC model can be used [58,68-70]. Moreover, here, as the targeted concentrations are extremely low in the ppb range, the key point is to evaluate the limit of detection of vQRS, to be able to extrapolate the response Ar down to this value.

\subsection{Biomarkers}

Chemo-resistive vapour sensors able to detect biomarkers in the exhaled breath of human beings have opened up a new era for early cancer diagnosis [71,72]. The discrimination between cancer patients and healthy subjects can be simply done through the comparison of their exhaled breath VOC profile via pattern recognition algorithms $[73,74]$. Recent studies using gas chromatography/mass spectroscopy (GC-MS) [75] linked with a preconcentrator have shown that the compounds of interest are generally to be found at 1-20 parts per billion (ppb) in healthy human breath [76,77]. However, VOC can also be seen in distinctive mixture compositions at higher levels from 10 to $3000 \mathrm{ppb}$ in the breath of cancer patients; for example, see Table 2 that summarizes some cancer biomarkers found in the breath $[78,79]$. The VOC biomarkers of cancer and other diseases can be broadly divided into polar and nonpolar compounds. The polar VOC belong to alcohols, carbonyl compounds like aldehydes and ketones, whereas nonpolar VOC are of two types, aliphatic hydrocarbons and aromatic hydrocarbons. However, the concentrations of alkanes and aromatic hydrocarbons in human breath are from $10 \mathrm{ppt}$ to $40 \mathrm{ppb}$, hence preconcentration becomes a very important step before analysis $[77,80,81]$. In this study we have selected seven of these biomarkers - ethanol, methanol, acetone, chloroform, benzene, toluene, cyclohexane and water-to illustrate the detection capabilities of our vQRS, being aware that only polar analytes can be detected without preconcentration. 
Table 2. Cancer biomarkers among breath volatile organic compound (VOC) [77-79,82,83], underlined vapours are used in this study.

\begin{tabular}{ccc}
\hline VOC Type & $\begin{array}{c}\text { Representative } \\
\text { Vapour Biomarkers }\end{array}$ & $\begin{array}{c}\text { Concentration Range in } \\
\text { Exhaled Breath (ppb) }\end{array}$ \\
\hline \multirow{2}{*}{ Alcohols } & Methanol & $157-344$ \\
& Ethanol & $96-2848$ \\
& 1-Propanol & $4-13$ \\
\hline \multirow{2}{*}{ Aldehydes } & Pentanal & $2-7$ \\
& Heptanal & $2-7$ \\
& Nonanal & $2-107$ \\
\hline \multirow{2}{*}{ Alkanes } & Pentane & $2-18$ \\
& 4-Methyloctane & $16-19$ \\
Halo hydrocarbons & Cyclohexane & $0.1-15$ \\
\hline \multirow{2}{*}{ Ketones } & Chloroform & 10 \\
& Acetone & $35-1000$ \\
Alkenes & 2-Butanone & $0.002-3$ \\
\hline \multirow{2}{*}{ Aromatics } & 3-Hydroxy-2- Butanone & $0.002-0.05$ \\
& Isoprene & $41-109$ \\
\hline & Ethyl benzene & $1-18$ \\
& Benzene & $1.1-3.5$ \\
\hline
\end{tabular}

\section{Results and Discussions}

\subsection{Characterization of Hybrid Nanocarbons}

\subsubsection{Atomic Force Microscopy (AFM)}

The three-dimensional AFM images of pristine CNT, GO and $\mathrm{C}_{60}$ are exhibited in Figure $2 \mathrm{a}-\mathrm{c}$, respectively. The diameters of the $\mathrm{C}_{60}$ nanoparticle clusters were calculated to be around $230 \mathrm{~nm}$ on an average. The comparison of an AFM image of pristine CNT with that of $\mathrm{C}_{60}$-g-CNT shown in Figure $2 \mathrm{~d}$, distinctly proves that a large number of $\mathrm{C}_{60}$ particles have been grafted onto CNT.

The pristine CNT appears to have a smooth cylindrical surface without any visible catalyst particles, whereas $\mathrm{C}_{60}$-g-CNT consists of many protrusions from the surface of $\mathrm{CNT}$, mostly at the junctions, which indicates that the $\mathrm{C}_{60}$ nanoparticles are grafted mostly at the junctions of entangled CNT network. On the other hand, the surface of the pristine $\mathrm{GO}$ nanosheets appears to be quite smooth, unlike that of $\mathrm{C}_{60}$ - $\mathrm{g}$-rGO shown in Figure 2e, where dotted clusters are clearly visible on the surface of the rGO nanosheets due to the grafting of $\mathrm{C}_{60}$ nanoparticles.

\subsubsection{Scanning Electronic Microscopy (SEM)}

Figure 3a shows SEM images of $\mathrm{C}_{60}$ nanoparticles when drop casted onto a silica substrate. Originally, polyhedral pentagonal hexagonal shaped particles of some hundred nanometres in diameter are observed. Figure $3 b, c$ exhibit SEM images of $C_{60}$, after dispersion in toluene abs sprayed onto silica substrate at high pressure at low and high resolution, respectively. Surprisingly, fullerene nanowhiskers (FNW) are formed in this case. It is reported by several researchers that $\mathrm{C}_{60}$ can be converted into FNW by the application of high temperature, pressure or velocity [84].

The interfacial polymerization of $\mathrm{C}_{60}$ nanoparticles may also produce $\mathrm{FNW}$ of diameter ranging from $300 \mathrm{~nm}$ to $1 \mu \mathrm{m}$ and length several micrometres $[85,86]$. Therefore, our case definitely provides an interesting finding where the spray layer-by-layer technique is proved to be a novel tool for production of fullerene nanowhiskers. The surface of $\mathrm{C}_{60}$-grGO shown in Figure $3 \mathrm{~d}$ is full of dotted clusters of $\mathrm{C}_{60}$ nanoparticles unlike that of pristine $\mathrm{rGO}$ as in Figure 3e, which supports the finding from AFM and confirms the presence of grafted $\mathrm{C}_{60}$ on the surface of rGO. By comparison of SEM images of CNT with $\mathrm{C}_{60}$-g-CNT as observed in Figure $3 f, g, C_{60}$ nanoclusters are found to be fully coated with CNT. 

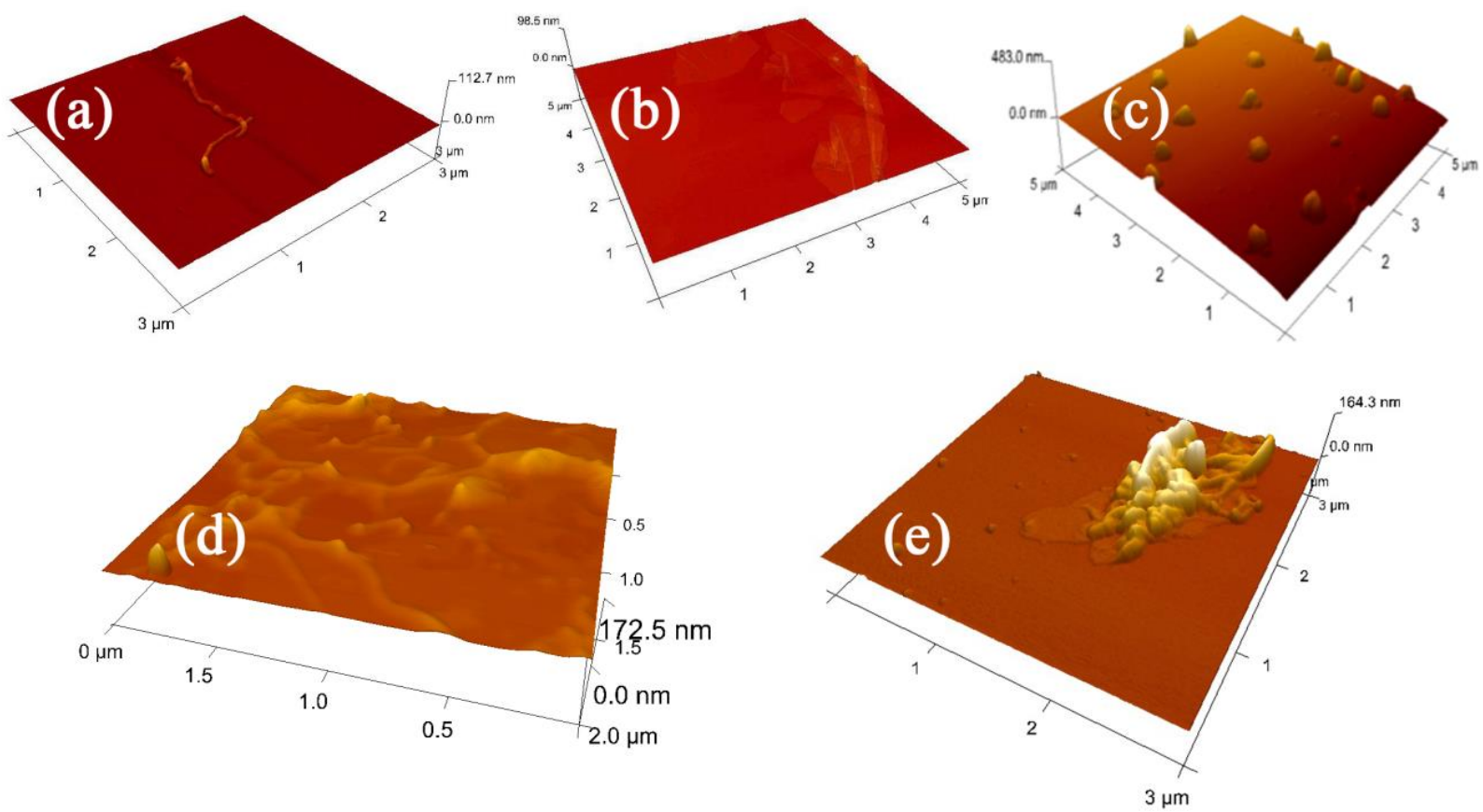

Figure 2. Atomic force microscopy (AFM) images of (a) CNT (NC 7000), (b) GO, (c) Buckminster fullerene ( $\left.\mathrm{C}_{60}\right)$, (d) $\mathrm{C}_{60}$-g-CNT and (e) $\mathrm{C}_{60}$-g-rGO.
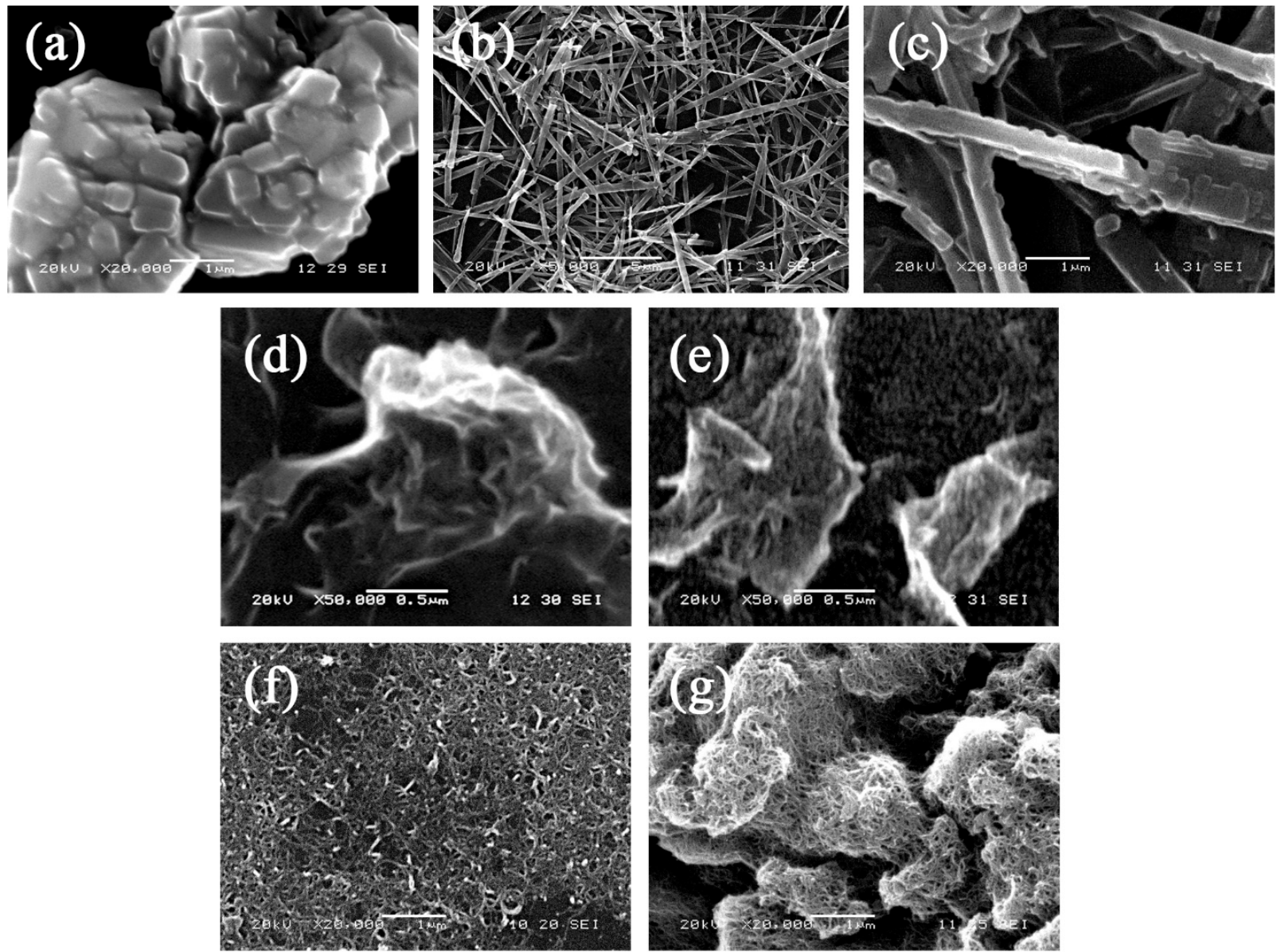

Figure 3. SEM images of (a) buckminsterfullerene $\left(\mathrm{C}_{60}\right)$ spin coated on silica substrate, $(\mathbf{b})$ and $(\mathbf{c}) \mathrm{C}_{60}$ sprayed on silica substrate (d) $\mathrm{rGO},(\mathbf{e}) \mathrm{C}_{60}$-g-rGO, (f) $\mathrm{CNT},(\mathrm{g}) \mathrm{C}_{60} 0^{-\mathrm{g}}$-CNT. 


\subsubsection{Thermo Gravimetric Analysis}

On Figure $4 \mathrm{C}_{60}$ undergoes only $3 \%$ weight loss up to $650{ }^{\circ} \mathrm{C}$, whereas around $9 \%$ weight loss takes place across the $650{ }^{\circ} \mathrm{C}$ to $800{ }^{\circ} \mathrm{C}$ temperature range. The slope of the decomposition curve changes clearly at around $650{ }^{\circ} \mathrm{C}$. rGO undergoes around $12 \%$ weight loss up to $800^{\circ} \mathrm{C}$ with the TGA curve following a continuous slope. $\mathrm{C}_{60}$-g-rGO, on the other hand, shows a combined decomposition trend. It decomposes by $30 \%$ up to $800{ }^{\circ} \mathrm{C}$, which may be due to the degradation of butyl group used as a linker between rGO and $\mathrm{C}_{60}$. Beyond $600{ }^{\circ} \mathrm{C}$ the slope of its decomposition curve is similar to that of $\mathrm{C}_{60}$, which proves successful grafting of $\mathrm{C}_{60}$ on to rGO. Similarly, $\mathrm{C}_{60}$-g-CNT undergoes around $20 \%$ weight loss up to $800{ }^{\circ} \mathrm{C}$ although the component nanomaterials like $\mathrm{CNT}$ and $\mathrm{C}_{60}$ degrade by $4 \%$ and $12 \%$, respectively.
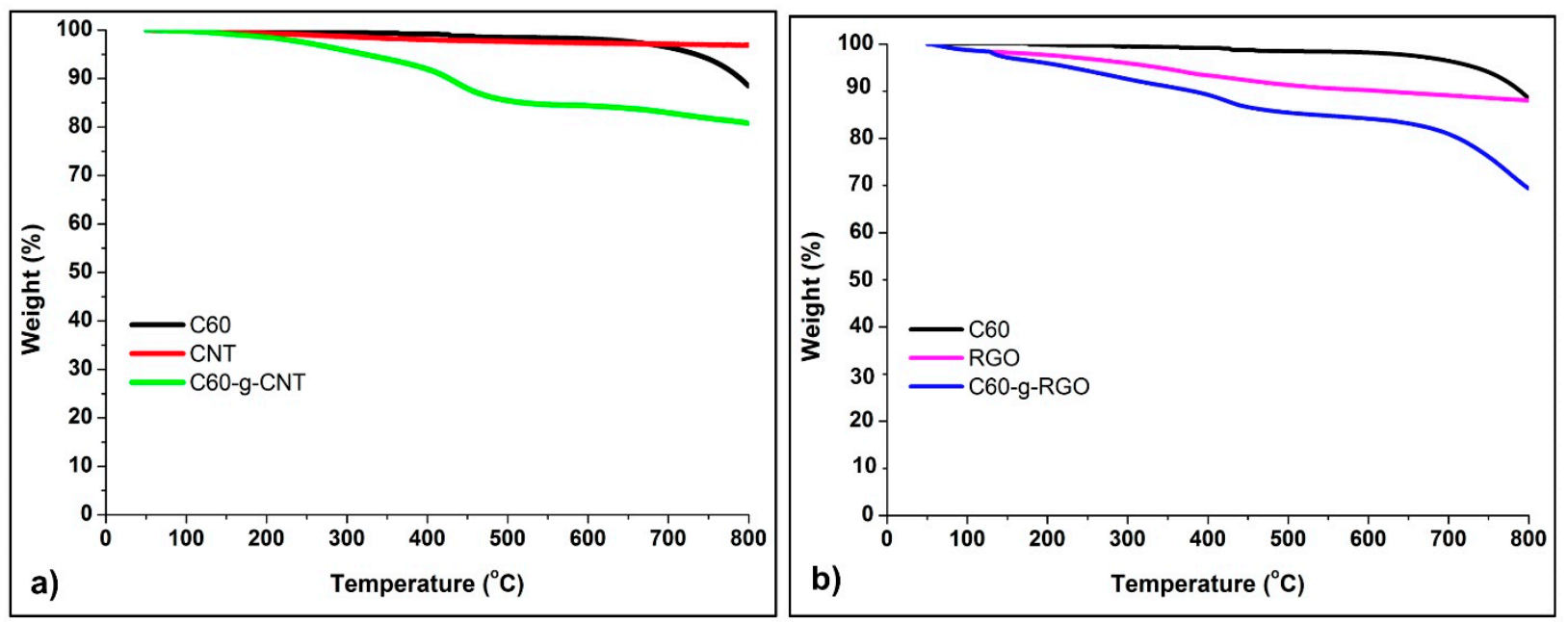

Figure 4. Compared thermogravimetric analysis curves of (a) $\mathrm{C}_{60}, \mathrm{rGO}$ and $\mathrm{C}_{60}$-g-rGO, (b) $\mathrm{C}_{60}, \mathrm{CNT}_{\text {and }} \mathrm{C}_{60}$-g-CNT nanohybrids

\subsection{Electrical Characterization of the Sensor \\ 3.2.1. Dynamic Vapour Sensing}

Figure 5 shows the normalized average maximum relative amplitude of a combination of three sensors CNT (NC 7000), $\mathrm{C}_{60}-\mathrm{l}-\mathrm{CNT}, \mathrm{C}_{60}-\mathrm{g}-\mathrm{CNT}$, when exposed to a set of eight VOC lung cancer biomarkers (ethanol, methanol, acetone, chloroform, benzene, toluene, cyclohexane and water) at $1000 \mathrm{ppb}$. The responses of all sensors upon exposure to analytes are recorded five times (see Figure $6 \mathrm{a}, \mathrm{b}$ for example) and their amplitude is calculated by making the average on the five signals, the first of which can sometimes be slightly different (see inlet of Figure 5), presumably due to a relaxation of the conducting network. As evident from Figure 5 the sensitivity of pristine CNT sensors underwent massive enhancement after hybridization with $\mathrm{C}_{60}$ either by layer after layer deposition in $\mathrm{C}_{60}-\mathrm{l}-\mathrm{CNT}$ or by covalent grafting in $\mathrm{C}_{60}-\mathrm{g}-\mathrm{CNT}$. This gives a very good illustration of the boosting effect of the grafting of $\mathrm{C}_{60}$ on $\mathrm{CNT}$, where it can be seen that the chemo-resistive response of $\mathrm{C}_{60}$-g-CNT based sensor to cyclohexane is twice that of $\mathrm{C}_{60}-\mathrm{CNT}$ and thirteen times that of the pristine carbon nanotubes. Additionally, it can be noted that the grafting of fullerene does not really change the selectivity of CNT sensors but it enhances the sensitivity of the same, dramatically keeping the order of selectivity same. The sensitivity of the sensors is directly proportional to the structure of the conductive architecture, whereas the difference in sensitivity of CNT based sensors to different VOC most likely results from specific interactions between the carbon species' surface and the analytes [43]. Moreover, as evident from the morphological images presented in Figure $3, \mathrm{C}_{60}$ is grafted mostly at the junctions of the CNT. Presence of spherical, strong electron acceptor $\mathrm{C}_{60}$ nanoparticles of exceptionally high surface to volume ratio at the CNT junctions can have a strong influence on the electronic mobility in the CNT network. This can induce a faster electronic transport, but also larger disturbances of this flow upon the adsorption of analytes, leading 
to a dramatic rise of sensitivity to a number of VOC. A strong influence on sensitivity naturally leads to an enhanced selectivity of sensors too. Thus, the grafting of $\mathrm{C}_{60}$ onto CNT leads to a sensor with a high inclination towards nonpolar VOC like cyclohexane, benzene, toluene, etc., although the principle of the doping of the sensing performances of the CNT network by the specific addition of fullerene is the same for both $\mathrm{C}_{60}-\mathrm{l}-\mathrm{CNT}$ (layer after layer deposited separately) and $\mathrm{C}_{60}-\mathrm{g}-\mathrm{CNT}$ (fullerene grafted onto CNT). However,

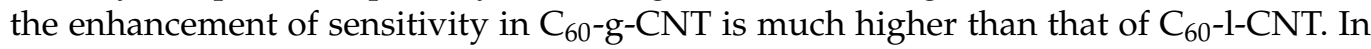
$\mathrm{C}_{60}$-g-CNT, the morphology is expected to be better controlled with $\mathrm{C}_{60}$ nanoparticles grafted at the junctions of $\mathrm{CNT}$, unlike $\mathrm{C}_{60}-\mathrm{l}-\mathrm{CNT}$ where one layer of $\mathrm{C}_{60}$ solution was deposited after the deposition of one layer of CNT solution onto the electrodes.

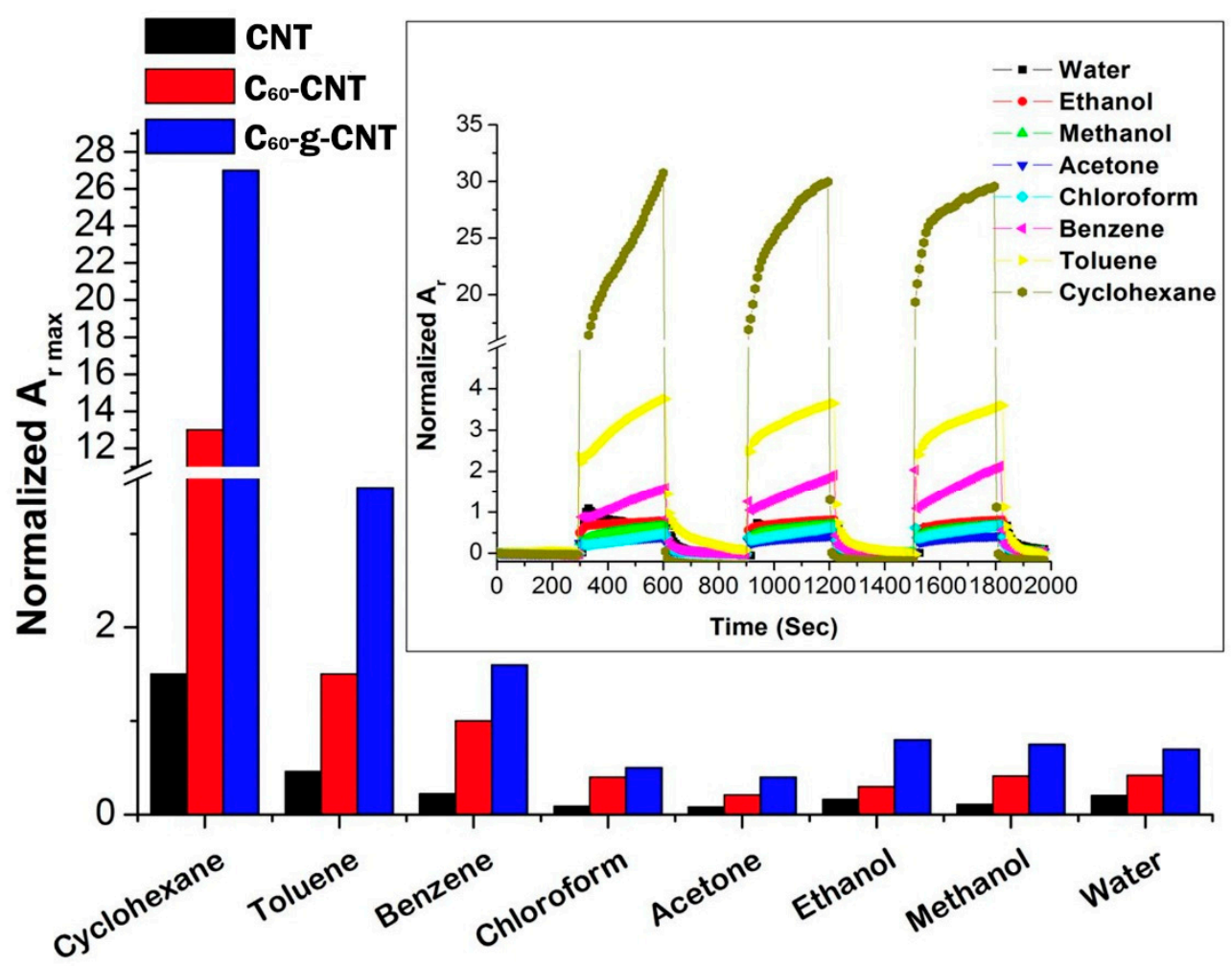

Figure 5. Normalized average maximum relative amplitude Ar of 3 kinds of sensors towards 8 VOC (equivalent to $1000 \mathrm{ppb}$ concentration). The inset image shows the chemo-resistive response of the $\mathrm{C}_{60}$-g-CNT sensors towards 8 VOC.

This finding is further supported by the comparison of the chemo-resistive signals of pristine rGO and $\mathrm{C}_{60}-\mathrm{g}-\mathrm{rGO}$ made in Figure $6 \mathrm{a}, \mathrm{b}$, respectively, which shows that the order of selectivity is the same for both. However, the sensitivity, i.e., the relative amplitudes were found to be much higher in case of $\mathrm{C}_{60}$-g-rGO sensors. It is clearly visible that rGObased sensors are about twenty times less sensitive than $\mathrm{C}_{60}$-g-rGO. Moreover, Figure $6 \mathrm{c}, \mathrm{d}$ confirm the interest of using spacers between nanosheets as already found [41,61], and also evidence the stabilizing effect of $\mathrm{C}_{60}$ at junctions leading to cleaner chemo-resistive responses even at the sub-ppm level.

The work presented here corresponds to the preliminary step in the design of an e-nose for breath analysis in order to diagnose severe diseases such as cancers, i.e., the determination of the selectivity and sensitivity to volatiles organic compounds considered as biomarkers of a considered disease. To go further it will be necessary to assemble more than 10 different $\mathrm{vQRS}$ of different selectivities into an array (e-nose) and to classify their responses with an algorithm such as PCA to be able to discriminate the different VOC into a 2D map, which was done there $[59,87,88]$. Another step consists of checking the influence of water molecules on the detection of biomarkers, as breath contains more than $80 \%$ moisture, which was done previously [89]. Therefore, it is believed that if 
sensors are not very sensitive to water, this drawback can be compensated by including a vQRS with a much higher sensitivity to water, such as chitosan functionalized CNT, for instance $[70,87,88]$, in the e-nose.
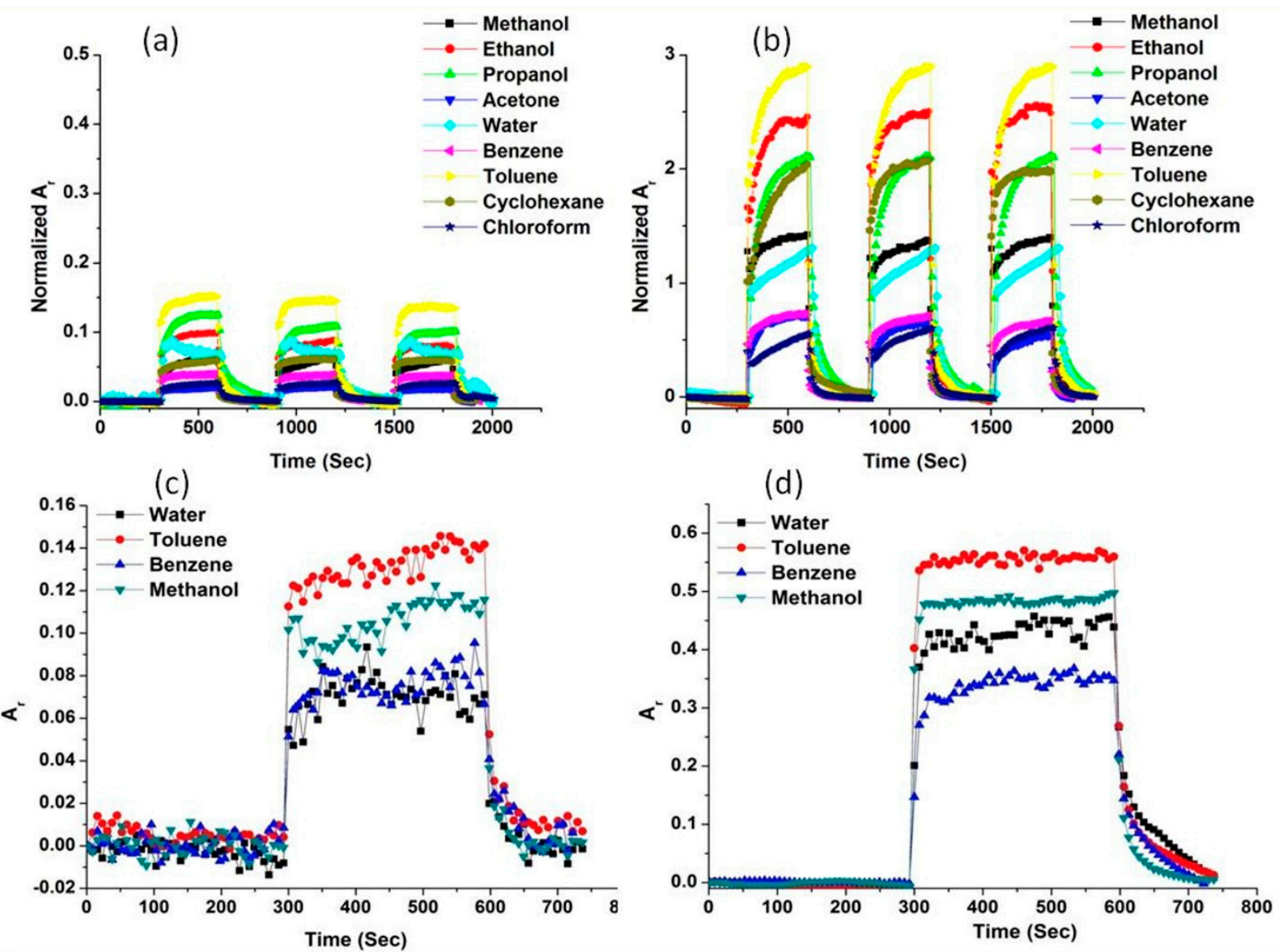

Figure 6. Chemo-resistive responses of (a) rGO and (b) $\mathrm{C}_{60}$-g-rGO sensors towards 8 VOC at 1000 ppb concentration. Focus on the chemo-resistive responses of (c) rGO and (d) $\mathrm{C}_{60}$-g-rGO sensors towards 4 selected VOCs at 400 ppb concentration.

\subsubsection{Limit of Detection at ppb Level}

Since breath extract consists of VOC mostly present at tiny concentrations, it is important to analyse the performance of our sensors under real conditions of ppb level exposure to VOC. In order to assess the efficiency of the sensors during sensing of trace level of vapour molecules in the surroundings, the signal-to-noise ratio (SNR) was measured according to Lewis et al. [90] using Equation (2).

$$
S N R=\frac{\Delta R_{\max }}{\sigma_{\text {baseline }}}
$$

where $\Delta R_{\max }=$ the steady-state resistance change upon exposing the sensor to solvent vapour molecules (analyte), i.e., the difference between the maximum resistance of a sensor obtained after exposure to a solvent and the baseline resistance of a sensor; $\sigma_{\text {baseline }}=$ the standard deviation in baseline resistance of the sensor before analyte delivery, calculated using 10 data points.

It is accepted that the chemo-resistive response can processed if its SNR value is higher than or equal to 2.0 (SNR $\geq 2.0$ ) at a defined concentration of solvent. Table 3 clearly demonstrates that the noise density of the rGO based sensors has been reduced considerably after the grafting of $\mathrm{C}_{60}$. 
Table 3. Signal-to-noise $(\mathrm{S} / \mathrm{N})$ ratio of $\mathrm{rGO}$ and $\mathrm{C}_{60}-\mathrm{g}-\mathrm{rGO}$ sensors towards four selected VOC at 400.ppb concentration.

\begin{tabular}{ccc}
\hline VOC & S/N [rGO] & S/N [C $\mathbf{6 0}_{\mathbf{6}}$-g-rGO $]$ \\
\hline Toluene & 61 & 109 \\
\hline Methanol & 30 & 224 \\
\hline Benzene & 18 & 231 \\
\hline Water & 19 & 153 \\
\hline
\end{tabular}

As also evident from Figure $6 c, d$, the enhancement of the sensitivity the of rGO based sensors by around four times, on grafting of the $\mathrm{C}_{60}$ even at $400 \mathrm{ppb}$ VOC concentration validates the reliability of our sensors even in sub-ppm level exposure of VOC.

\section{Conclusions}

It has been demonstrated in this paper that the grafting of Buckminster fullerenes at the junctions of CNT or graphene networks can strongly boost the sensitivity and the selectivity of the conducting architecture of chemo-resistive vapour sensors. It has been assumed that the enhancement of the electronic mobility through the CNT or graphene network, due to the grafting at junctions of spherical Buckminster fullerene with high surface area, is the most likely reason for the important gain of sensing properties obtained. Given that the major limitation of crude CNT or graphene-based sensors results from their too low and nonadjustable selectivity to volatile organic compounds, this work shows that such a lock can be lifted by synthesizing their nanohybrids based on Buckminster fullerene, which improves by tenfold the performances of crude carbon nanotubes or graphene-based sensors. Although the ranking of selectivity towards the different selected VOC remained the same, the increase in sensitivity automatically led to the enhancement of the sensors' discrimination ability. Thus, it can be concluded that grafting $\mathrm{C}_{60}$ at the nanojunctions of a carbon nanoarchitecture by covalent or noncovalent functionalization is a powerful tool to tune both sensitivity and selectivity of carbon-based nanosensors without functionalization by polymers as usually done. The present study unveils an innovative approach for boosting chemo-resistive transducers by improving the electronic mobility of their junctions through the grafting of Buckminster fullerenes thanks to their high surface area. These promising results are expected to bring an interesting input in the design of sharper sensor arrays for volatolomics in order to make the anticipated diagnostics of severe diseases like cancers more reliable. However, the study also points out that among all selected biomarkers, only ethanol, methanol, acetone, chloroform, and water can be detected directly by our vQRS when they present in breath at a concentration close to $400 \mathrm{ppb}$. Nonpolar analytes such as benzene, toluene, and cyclohexane, being under the limit of detection in breath, will require a preconcentration step before analysis as expected.

Author Contributions: Data Curation, S.N.; Writing-Original Draft Preparation, S.N.; WritingReview \& Editing, J.-F.F., M.C. and V.C.; Supervision, J.-F.F., M.C. and V.C. All authors have read and agreed to the published version of the manuscript.

Funding: The authors thank the University of South Brittany (UBS Lorient), and the Indian Institute of Technology (IIT Delhi) for funding.

Institutional Review Board Statement: Not applicable.

Informed Consent Statement: Not applicable.

Data Availability Statement: Data available on request due to restrictions eg privacy or ethical.

Acknowledgments: The authors thank Hervé BELLÉGOU and Isabelle PILLIN for their contribution to this work. 
Conflicts of Interest: The authors declare no conflict of interest.

\section{References}

1. Haick, H.; Broza, Y.Y.; Mochalski, P.; Ruzsanyi, V.; Amann, A. Assessment, origin, and implementation of breath volatile cancer markers. Chem. Soc. Rev. 2014, 43, 1423-1449. [CrossRef] [PubMed]

2. Jin, H.; Yu, J.; Lin, S.; Gao, S.; Yang, H.; Haick, H.; Hua, C.; Deng, S.; Yang, T.; Liu, Y.; et al. Nanosensor-based flexible electronic assisted with light fidelity communicating technology for volatolomics-based telemedicine. ACS Nano 2020, 14, 15517-15532. [CrossRef] [PubMed]

3. Xu, Z.Q.; Broza, Y.Y.; Ionsecu, R.; Tisch, U.; Ding, L.; Liu, H.; Song, Q.; Pan, Y.Y.; Xiong, F.X.; Gu, K.S.; et al. A nanomaterial-based breath test for distinguishing gastric cancer from benign gastric conditions. Br. J. Cancer 2013, 108, 941-950. [CrossRef]

4. Santonico, M.; Lucantoni, G.; Pennazza, G.; Capuano, R.; Galluccio, G.; Roscioni, C.; La Delfa, G.; Consoli, D.; Martinelli, E.; Paolesse, R.; et al. In situ detection of lung cancer volatile fingerprints using bronchoscopic air-sampling. Lung Cancer 2012, 77, 46-50. [CrossRef]

5. Nakhleh, M.K.; Amal, H.; Jeries, R.; Broza, Y.Y.; Aboud, M.; Gharra, A.; Ivgi, H.; Khatib, S.; Badarneh, S.; Har-Shai, L.; et al. Diagnosis and classification of 17 diseases from 1404 subjects via pattern analysis of exhaled molecules. ACS Nano 2017, 11, 112-125. [CrossRef]

6. Tripathi, K.M.; Sachan, A.; Castro, M.; Choudhary, V.; Sonkar, S.K.; Feller, J.F. Green carbon nanostructured quantum resistive sensors to detect volatile biomarkers. Sustain. Mater. Technol. 2018, 16, 1-11. [CrossRef]

7. Peng, G.; Trock, E.; Haick, H. Detecting simulated patterns of lung cancer biomarkers by random network of single-walled carbon nanotubes coated with nonpolymeric organic materials. Nano Lett. 2008, 8, 3631-3635. [CrossRef] [PubMed]

8. Duarte, L.; Nag, S.; Castro, M.; Zaborova, E.; Ménand, M.; Sollogoub, M.; Bennevault, V.; Feller, J.F.; Guégan, P. Chemical Sensors Based on New Polyamides Biobased on (Z) Octadec-9-Enedioic Acid and $\beta$-Cyclodextrin. Macromol. Chem. Phys. 2016, 217, 1620-1628. [CrossRef]

9. Peng, G.; Hakim, M.; Broza, Y.Y.; Billan, S.; Abdah-Bortnyak, R.; Kuten, A.; Tisch, U.; Haick, H. Detection of lung, breast, colorectal, and prostate cancers from exhaled breath using a single array of nanosensors. Br. J. Cancer 2010, 103, 542-551. [CrossRef]

10. Turner, C.; Knobloch, H.; Richards, J.; Richards, P.; Mottram, T.T.F.; Marlin, D.; Chambers, M.A. Development of a device for sampling cattle breath. Biosyst. Eng. 2012, 112, 75-81. [CrossRef]

11. Bruins, M.; Rahim, Z.; Bos, A.; van de Sande, W.W.J.; Endtz, H.P.; van Belkum, A. Diagnosis of active tuberculosis by e-nose analysis of exhaled air. Tuberculosis 2013, 93, 232-238. [CrossRef] [PubMed]

12. Wlodzimirow, K.A.; Abu-Hanna, A.; Schultz, M.J.; Maas, M.A.; Bos, L.D.J.; Sterk, P.J.; Knobel, H.H.; Soers, R.J.T.; Chamuleau, R.A.F.M. Exhaled breath analysis with electronic nose technology for detection of acute liver failure in rats. Biosens. Bioelectron. 2014, 53, 129-134. [CrossRef] [PubMed]

13. Peng, G.; Tisch, U.; Haick, H. Detection of nonpolar molecules by means of carrier scattering in random networks of carbon nanotubes: Toward diagnosis of diseases via breath samples. Nano Lett. 2009, 9, 1362-1368. [CrossRef] [PubMed]

14. Tisch, U.; Schlesinger, I.; Ionescu, R.; Nassar, M.; Axelrod, N.; Robertman, D.; Tessler, Y.; Azar, F.; Marmur, A.; Aharon-Peretz, J.; et al. Detection of Alzheimer's and Parkinson's disease from exhaled breath using nanomaterial-based sensors. Nanomedicine 2013, 8, 43-56. [CrossRef]

15. Zilberman, Y.; Tisch, U.; Shuster, G.; Pisula, W.; Feng, X.; Müllen, K.; Haick, H. Carbon nanotube/hexa-peri-hexabenzocoronene bilayers for discrimination between nonpolar Volatile Organic Compounds of cancer and humid atmospheres. Adv. Mater. 2010, 22, 4317-4320. [CrossRef]

16. Kumar, B.; Castro, M.; Feller, J.F. Quantum resistive vapour sensors made of polymer coated carbon nanotubes random networks for biomarkers detection. Chem. Sens. 2013, 3, 1-7.

17. Mashir, A.; Dweik, R.A. Exhaled breath analysis: The new interface between medicine and engineering. Adv. Powder Technol. 2009, 20, 420-425. [CrossRef]

18. Ionescu, R.; Broza, Y.Y.; Shaltieli, H.; Sadeh, D.; Zilberman, Y.; Feng, X.; Glass-Marmor, L.; Lejbkowicz, I.; Müllen, K.; Miller, A.; et al. Detection of multiple sclerosis from exhaled breath using bilayers of polycyclic aromatic hydrocarbons and single-wall carbon nanotubes. ACS Chem. Neurosci. 2011, 2, 687-693. [CrossRef] [PubMed]

19. Tran, M.T. Development of Nanocomposite Quantum Resistive Sensors for the Prevention of Bedsores; University of South Brittany (UBS): Lorient, France, 2018.

20. Gibson, T.D.; Prosser, O.; Hulbert, J.N.; Marshall, R.W.; Corcoran, P.; Lowery, P.; Ruck-Keene, E.A.; Heron, S. Detection and simultaneous identification of microorganisms from headspace samples using an electronic nose. Sens. Actuators B Chem. 1997, 44, 413-422. [CrossRef]

21. Fleming-Jones, M.E.; Smith, R.E. Volatile organic compounds in foods: A five year study. J. Agric. Food Chem. 2003, 51, 8120-8127. [CrossRef] [PubMed]

22. Tung, T.T.; Castro, M.; Kim, T.Y.; Suh, K.S.; Feller, J.F. Graphene quantum resistive sensing skin for the detection of alteration biomarkers. J. Mater. Chem. 2012, 22, 21754-21766. [CrossRef]

23. Ho, C.; Robinson, A.; Miller, D.; Davis, M. Overview of sensors and needs for environmental monitoring. Sensors 2005, 5, 4-37. [CrossRef] 
24. Lamagna, A.; Reich, S.; Rodríguez, D.; Boselli, A.; Cicerone, D. The use of an electronic nose to characterize emissions from a highly polluted river. Sens. Actuators B Chem. 2008, 131, 121-124. [CrossRef]

25. Su, S.; Wu, W.; Gao, J.; Lu, J.; Fan, C. Nanomaterials-based sensors for applications in environmental monitoring. J. Mater. Chem. 2012, 22, 18101-18110. [CrossRef]

26. Sachan, A.; Castro, M.; Choudhary, V.; Feller, J.F. vQRS based on hybrids of CNT with PMMA-POSS and PS-POSS copolymers to reach the sub-ppm detection of ammonia and formaldehyde at room temperature despite moisture. ChemoSensors $2017,5,22$. [CrossRef]

27. Sekhar, P.K.; Brosha, E.L.; Mukundan, R.; Garzon, F. Chemical sensors for environmental monitoring and homeland security. Electrochem. Soc. Interface 2010, 19, 35-40. [CrossRef]

28. Zhang, S.W.; Swager, T.M. Fluorescent detection of chemical warfare agents: Functional group specific ratiometric chemosensors. J. Am. Chem. Soc. 2003, 125, 3420-3421. [CrossRef]

29. Wang, Y.; Yang, Z.; Hou, Z.; Xu, D.; Wei, L.; Kong, E.S.W.; Zhang, Y. Flexible gas sensors with assembled carbon nanotube thin films for DMMP vapor detection. Sens. Actuators B Chem. 2010, 150, 708-714. [CrossRef]

30. Laquintinie, P.S.; Sachan, A.; Feller, J.F.; Lahuec, C.; Castro, M.; Seguin, F.; Dupont, L. An electronic nose prototype for the on-field detection of nerve agents. In IEEE Sensors; IEEE: New-Delhi, India, 2018; pp. 1-4.

31. Haddi, Z.; Mabrouk, S.; Bougrini, M.; Tahri, K.; Sghaier, K.; Barhoumi, H.; El Bari, N.; Maaref, A.; Jaffrezic-Renault, N.; Bouchikhi, B. E-Nose and e-Tongue combination for improved recognition of fruit juice samples. Food Chem. 2014, 150, 246-253. [CrossRef] [PubMed]

32. Sobański, T.; Szczurek, A.; Nitsch, K.; Licznerski, B.W.; Radwan, W. Electronic nose applied to automotive fuel qualification. Sens. Actuators B Chem. 2006, 116, 207-212. [CrossRef]

33. Benvenho, A.R.V.; Li, R.W.C.; Gruber, J. Polymeric electronic gas sensor for determining alcohol content in automotive fuels. Sens. Actuators B Chem. 2009, 136, 173-176. [CrossRef]

34. Cikach, F.S.; Dweik, R.A. Cardiovascular biomarkers in exhaled breath. Prog. Cardiovasc. Dis. 2012, 55, 34-43. [CrossRef] [PubMed]

35. Wudl, F. Fullerene materials. J. Mater. Chem. 2002, 12, 1959-1963. [CrossRef]

36. Feller, J.F. 6.10 Electrically Conductive Nanocomposites. In Comprehensive Composite Materials II; Beaumont, P.W.R., Zweben, C.H., Eds.; Elsevier: Amsterdam, The Netherlands, 2018; pp. 248-314.

37. Schedin, F.; Geim, A.K.; Morozov, S.V.; Hill, E.W.; Blake, P.; Katsnelson, M.I.; Novoselov, K.S. Detection of individual gas molecules adsorbed on graphene. Nat. Mater. 2007, 6, 652-655. [CrossRef]

38. Novoselov, K.S.; Geim, A.K.; Morozov, S.V.; Jiang, D.; Katsnelson, M.I.; Grigorieva, I.V.; Dubonos, S.V.; Firsov, A.A. Twodimensional gas of massless Dirac fermions in graphene. Nature 2005, 438, 197-200. [CrossRef]

39. Geim, A.K.; Novoselov, K.S. The rise of graphene. Nat. Mater. 2007, 6, 183-191. [CrossRef]

40. Zhang, B.; Li, Q.; Cui, T. Ultra-sensitive suspended graphene nanocomposite cancer sensors with strong suppression of electrical noise. Biosens. Bioelectron. 2012, 31, 105-109. [CrossRef] [PubMed]

41. Nag, S.; Duarte, L.; Bertrand, E.; Celton, V.; Castro, M.; Choudhary, V.; Guégan, P.; Feller, J.F. Ultrasensitive QRS made by supramolecular assembly of functionalized cyclodextrins and graphene for the detection of lung cancer VOC biomarkers. J. Mater. Chem. B Biol. Med. 2014, 2, 6571-6579. [CrossRef] [PubMed]

42. Goldoni, A.; Petaccia, L.; Lizzit, S.; Larciprete, R. Sensing gases with carbon nanotubes: A review of the actual situation. J. Phys. Condens. Matter 2010, 22, 013001. [CrossRef]

43. Feller, J.F.; Gatt, N.; Kumar, B.; Castro, M. Selectivity of chemoresistive sensors made of chemically functionalized carbon nanotube random networks for volatile organic compounds (VOC). ChemoSensors 2014, 2, 26-40. [CrossRef]

44. Kroto, H.W.; Heath, J.R.; O’Brien, S.C.; Curl, R.F.; Smalley, R.E. C60: Buckminsterfullerene. Nature 1985, 318, 162-163. [CrossRef]

45. Krätschmer, W.; Lamb, L.D.; Fostiropoulos, K.; Huffman, D.R. Solid C60: A new form of carbon. Nature 1990, 347, 354-358. [CrossRef]

46. Jin, Y.; Curry, R.J.; Sloan, J.; Hatton, R.A.; Chong, L.C.; Blanchard, N.; Stolojan, V.; Kroto, H.W.; Silva, S.R.P. Structural and optoelectronic properties of C60 rods obtained via a rapid synthesis route. J. Mater. Chem. 2006, 16, 3715. [CrossRef]

47. Krusic, P.J.; Wasserman, E.; Keizer, P.N.; Morton, J.R.; Preston, K.F. Radical reactions of C60. Science 1991, $254,1183-1185$. [CrossRef] [PubMed]

48. Somani, P.R.; Somani, S.P.; Umeno, M. Toward organic thick film solar cells: Three dimensional bulk heterojunction organic thick film solar cell using fullerene single crystal nanorods. Appl. Phys. Lett. 2007, 91, 173503. [CrossRef]

49. Zhang, X.; Qu, Y.; Piao, G.; Zhao, J.; Jiao, K. Reduced working electrode based on fullerene C60 nanotubes@DNA: Characterization and application. Mater. Sci. Eng. B 2010, 175, 159-163. [CrossRef]

50. Zhao, Y.; Kim, Y.H.; Dillon, A.C.; Heben, M.J.; Zhang, S.B. Hydrogen storage in novel organometallic buckyballs. Phys. Rev. Lett. 2005, 94, 155504. [CrossRef]

51. Ohashi, T.; Dai, L. C60 and carbon nanotube sensors. In Carbon Nanotechnology; Dai, L., Ed.; Elsevier: Amsterdam, The Netherlands, 2006; pp. 525-575. ISBN 9780444518552.

52. Yu, D.; Park, K.; Durstock, M.; Dai, L. Fullerene-grafted graphene for efficient bulk heterojunction polymer photovoltaic devices. J. Phys. Chem. Lett. 2011, 2, 1113-1118. [CrossRef] 
53. Li, C.; Chen, Y.; Wang, Y.; Iqbal, Z.; Mitra, S. A fullerene-Single wall carbon nanotube complex for polymer bulk heterojunction photovoltaic cells. J. Mater. Chem. 2007, 17, 2406-2411. [CrossRef]

54. Liu, Z.B.; Xu, Y.F.; Zhang, X.Y.; Zhang, X.L.; Chen, Y.S.; Tian, J.G. Porphyrin and fullerene covalently functionalized graphene hybrid materials with large nonlinear optical properties. J. Phys. Chem. B 2009, 113, 9681-9686. [CrossRef]

55. Zhang, X.; Huang, Y.; Wang, Y.; Ma, Y.; Liu, Z.; Chen, Y. Synthesis and characterization of a graphene-C60 hybrid material. Carbon N. Y. 2009, 47, 334-337. [CrossRef]

56. Song, P.; Shen, Y.; Du, B.; Guo, Z.; Fang, Z. Fabrication of fullerene-decorated carbon nanotubes and their application in flame-retarding polypropylene. Nanoscale 2009, 1, 118-121. [CrossRef] [PubMed]

57. Girifalco, L.A.; Hodak, M.; Lee, R.S. Carbon nanotubes, buckyballs, ropes, and a universal graphitic potential. Phys. Rev. B 2000, 62, 13104-13110. [CrossRef]

58. Feller, J.F.; Lu, J.; Zhang, K.; Kumar, B.; Castro, M.; Gatt, N.; Choi, H.J. Novel architecture of carbon nanotube decorated poly(methyl methacrylate) microbead vapour sensors assembled by spray layer by layer. J. Mater. Chem. 2011, 21, 4142-4149. [CrossRef]

59. Nag, S.; Sachan, A.; Castro, M.; Choudhary, V.; Feller, J.F. Spray layer-by-layer assembly of POSS functionalized CNT quantum chemo-resistive sensors with tuneable selectivity and ppm resolution to VOC biomarkers. Sens. Actuators B Chem. 2016, 222, 362-373. [CrossRef]

60. Tung, T.T.; Castro, M.; Kim, T.Y.; Suh, K.S.; Feller, J.F. High stability silver nanoparticles-graphene/poly(ionic liquid)-based chemoresistive sensors for volatile organic compounds' detection. Anal. Bioanal. Chem. 2014, 406, 3995-4004. [CrossRef]

61. Tung, T.T.; Castro, M.; Pillin, I.; Kim, T.Y.; Suh, K.S.; Feller, J.-F. Graphene-Fe3O4/PIL-PEDOT for the design of sensitive and stable quantum chemo-resistive VOC sensors. Carbon N. Y. 2014, 74, 104-112. [CrossRef]

62. Tung, T.T.; Feller, J.F.; Kim, T.Y.; Kim, H.K.; Yang, W.S.; Suh, K.S. Electromagnetic properties of Fe3O4-functionalized graphene and its composites with a conducting polymer. J. Polym. Sci. A Chem. 2012, 50, 927-935. [CrossRef]

63. Tung, T.T.; Castro, M.; Feller, J.F. Electronic noses for VOCs detection based on the nanoparticles hybridized graphene composites. In Proceedings of the 12th IEEE International Conference on Nanotechnology (IEEE-NANO), Birmingham, UK, 20-23 August 2012; IEEE: Piscataway, NJ, USA, 2012; pp. 1-5.

64. Hummers, W.S.; Offeman, R.E. Preparation of graphitic oxide. J. Am. Chem. Soc. 1958, 80, 1339. [CrossRef]

65. Chatterjee, S.; Castro, M.; Feller, J.F. An e-nose made of carbon nanotube based quantum resistive sensors for the detection of eighteen polar/nonpolar VOC biomarkers of lung cancer. J. Mater. Chem. B 2013, 1, 4563. [CrossRef]

66. Nag, S.; Castro, M.; Choudhary, V.; Feller, J.F. Sulfonated poly(ether ether ketone) [SPEEK] nanocomposites based on hybrid nanocarbons for the detection and discrimination of some lung cancer VOC biomarkers. J. Mater. Chem. B Biol. Med. 2017, 5, 348-359. [CrossRef] [PubMed]

67. Tung, T.T.; Pham-Huu, C.; Janowska, I.; Kim, T.Y.; Castro, M.; Feller, J.F. Hybrid films of graphene and carbon nanotubes for high performance chemical and temperature sensing applications. Small 2015, 11, 3485-3493. [CrossRef] [PubMed]

68. Feller, J.F.; Kumar, B.; Castro, M. Conductive biopolymer nanocomposites for sensors. In Nanocomposites with Biodegradable Polymers: Synthesis, Properties \& Future Perspectives; Mital, V., Ed.; Oxford University Press: Oxford, UK, 2011; pp. 368-399; ISBN 9780199581924.

69. Lu, J.; Kumar, B.; Castro, M.; Feller, J.F. Vapour sensing with conductive polymer nanocomposites (CPC): Polycarbonate-carbon nanotubes transducers with hierarchical structure processed by spray layer by layer. Sens. Actuators B Chem. 2009, 140, 451-460. [CrossRef]

70. Bouvrée, A.; Feller, J.-F.; Castro, M.; Grohens, Y.; Rinaudo, M. Conductive Polymer nano-bioComposites (CPC): Chitosan-carbon nanoparticle a good candidate to design polar vapour sensors. Sens. Actuators B Chem. 2009, 138, 138-147. [CrossRef]

71. Mazzone, P. Sniffing out lung cancer. Nat. Nanotechnol. 2009, 4, 621-622. [CrossRef] [PubMed]

72. D'Amico, A.; Di Natale, C.; Paolesse, R.; Macagnano, A.; Martinelli, E.; Pennazza, G.; Santonico, M.; Bernabei, M.; Roscioni, C.; Gallucio, G. Olfactory systems for medical applications. Sens. Actuators B Chem. 2008, 130, 458-465. [CrossRef]

73. Silva, C.L.; Passos, M.; Câmara, J.S. Solid phase microextraction, mass spectrometry and metabolomic approaches for detection of potential urinary cancer biomarkers-A powerful strategy for breast cancer diagnosis. Talanta 2012, 89, 360-368. [CrossRef] [PubMed]

74. Hockstein, N.G.; Thaler, E.R.; Torigian, D.; Miller, W.T.; Deffenderfer, O.; Hanson, C.W. Diagnosis of pneumonia with an electronic nose: Correlation of vapor signature with chest computed tomography scan findings. Laryngoscope 2004, 114, 1701-1705. [CrossRef]

75. Deng, C.; Zhang, X.; Li, N. Investigation of volatile biomarkers in lung cancer blood using solid-phase microextraction and capillary gas chromatography-mass spectrometry. J. Chromatogr. B 2004, 808, 269-277. [CrossRef]

76. Liu, F.L.; Xiao, P.; Fang, H.L.; Dai, H.F.; Qiao, L.; Zhang, Y.H. Single-walled carbon nanotube-based biosensors for the detection of volatile organic compounds of lung cancer. Phys. E Low-Dimens. Syst. Nanostruct. 2011, 44, 367-372. [CrossRef]

77. O'Neill, H.J.; Gordon, S.N.; O'Neill, M.H.; Gibbons, R.D.; Szidon, J.P. A computerized in lung cancer technique for screening for the presence of breath biomarkers. Clin. Chem. 1988, 34, 1613-1618. [CrossRef] [PubMed]

78. Hanna, G.B.; Boshier, P.R.; Markar, S.R.; Romano, A. Accuracy and methodologic challenges of volatile organic compound-based exhaled breath tests for cancer diagnosis. JAMA Oncol. 2019, 5, e182815. [CrossRef] [PubMed] 
79. Tomić, M.; Šetka, M.; Vojkůvka, L.; Vallejos, S. VOC sensing by metal oxides, conductive polymers, and carbon-based materials. Nanomaterials 2021, 11, 552. [CrossRef]

80. Cho, S.M.; Kim, Y.J.; Heo, G.S.; Shin, S.M. Two-step preconcentration for analysis of exhaled gas of human breath with electronic nose. Sens. Actuators B Chem. 2006, 117, 50-57. [CrossRef]

81. Yu, H.; Xu, L.; Wang, P. Solid phase microextraction for analysis of alkanes and aromatic hydrocarbons in human breath. J. Chromatogr. B 2005, 826, 69-74. [CrossRef]

82. Machado, R.F.; Laskowski, D.; Deffenderfer, O.; Burch, T.; Zheng, S.; Mazzone, P.J.; Mekhail, T.; Jennings, C.; Stoller, J.K.; Pyle, J.; et al. Detection of lung cancer by sensor array analyses of exhaled breath. Am. J. Respir. Crit. Care Med. 2005, 171, 1286-1291. [CrossRef]

83. Dragonieri, S.; van der Schee, M.P.; Massaro, T.; Schiavulli, N.; Brinkman, P.; Pinca, A.; Carratú, P.; Spanevello, A.; Resta, O.; Musti, M.; et al. An electronic nose distinguishes exhaled breath of patients with Malignant Pleural Mesothelioma from controls. Lung Cancer 2012, 75, 326-331. [CrossRef]

84. Li, G.; Liu, P.; Han, Z.; Piao, G.; Zhao, J.; Li, S.; Liu, G. A novel approach to fabrication of fullerene C60 nanotubes: Using C60-Pyridine colloid as a precursor. Mater. Lett. 2010, 64, 483-485. [CrossRef]

85. Li, G.; Han, Z.; Piao, G.; Zhao, J.; Li, S.; Liu, G. To distinguish fullerene C60 nanotubes and C60 nanowhiskers using Raman spectroscopy. Mater. Sci. Eng. B 2009, 163, 161-164. [CrossRef]

86. Sathish, M.; Miyazawa, K. Synthesis and characterization of fullerene nanowhiskers by liquid-liquid interfacial precipitation: Influence of C60 solubility. Molecules 2012, 17, 3858-3865. [CrossRef]

87. Feller, J.F.; Castro, M.; Kumar, B. Polymer-carbon nanotube conductive nanocomposites for sensing. In Polymer-Carbon Nanotube Composites: Preparation, Properties and Applications; McNally, T., Pötschke, P., Eds.; Woodhead Publishing Limited: Cambridge, UK, 2011; pp. 760-803. ISBN 1845697618.

88. Kumar, B.; Castro, M.; Feller, J.F. Controlled conductive junction gap for chitosan-carbon nanotube quantum resistive vapour sensors. J. Mater. Chem. 2012, 22, 10656-10664. [CrossRef]

89. Sachan, A.; Castro, M.; Choudhary, V.; Feller, J.F. Influence of water molecules on the detection of volatile organic compounds (VOC) cancer biomarkers by nanocomposite quantum resistive vapor sensors vQRS. Chemosensors 2018, 6, 64. [CrossRef]

90. Gao, T.; Woodka, M.D.; Brunschwig, B.S.; Lewis, N.S. Chemiresistors for array-based vapor sensing using composites of carbon black with low volatility organic molecules. Chem. Mater. 2006, 18, 5193-5202. [CrossRef] 